\title{
Painting with the Multiple Intelligences: Defining Student Success and Permanence in Art Class
}

\author{
Şeyda Eraslan Taşpınar ${ }^{1}$, Ali Kaya ${ }^{2}$ \\ ${ }^{1}$ Atatürk University, Kazım Karabekir Education Faculty, Visual Art Education Department, Erzurum, 25240, Turkey \\ ${ }^{2}$ Atatürk Secondary School, Iğdır, Turkey \\ Correspondence: Şeyda Eraslan Taşpınar, Atatürk University, Kazım Karabekir Education Faculty, Visual Art Education \\ Department, Erzurum, 25240, Turkey, 90442 2313550-253. E-mail: seraslan@ atauni.edu.tr
}

Received: March 31, 2016 Accepted: April 13, $2016 \quad$ Online Published: June 21, 2016

doi:10.11114/jets.v4i7.1684 URL: http://dx.doi.org/10.11114/jets.v4i7.1684

\begin{abstract}
Objectives of the study are to determine the effect of teaching based on multiple intelligence theory (TBMIT) in visual arts class on student success and permanence. Experimental design is used in the study. Study group is composed of students at $8^{\text {th }}$ grade in 2012-2013 educational term at Atatürk Secondary School in Iğdır city centre. Experimental and control groups are made up of 32 and 31 students, respectively. In control group, conventional teaching method was used for expressing the subject of "miniature picture" in visual arts class while in experimental group a teaching method based on multiple intelligence theory (MIT) was applied for 3 weeks in both groups. Success test developed by the researchers was applied to measure success readily after and permanence of the knowledge learned 3 weeks after the experiment. In the comparison of the results obtained from Success and Permanence tests of experiment and control groups, $t$ test was used by considering the statistical analyses of data obtained. It was found form the results that experimental group is more successful than control on the average. According to $\mathrm{P}$ test results, experimental group had larger P scores than the control. As a conclusion, MIT was found to affect Success and Permanence of $8^{\text {th }}$ grade students in miniature picture subject in visual arts class.
\end{abstract}

Keywords: education, art, art education, visual arts, multiple intelligence theory

\section{Introduction}

Art is a universal area where individuals can express themselves freely. It has a visual expression language. Individuals can perceive this visual language in different forms and also produce unique manners by combining their sense and thoughts with skills and creativity. This characteristic of art results from the differences of individual skills and learning patterns. Just as physical appearance of individual is different from others, individual learning and perception patterns and skills are also different from each other.

Acceptance of the existence of individuals learning in different ways brings together learning - teaching process through different tools. Individual differences required new teaching techniques, strategies and methods to develop.

Erden and Akman (2009) stated that teaching programs should be prepared for common characteristics of students in order for all students in classroom to be successful and to obtain an effective teaching and one should bear in mind that each student has unique characteristics and they should be offered alternative activities suitable for their individual characteristics. Parasiz (2009) also reports the importance of that for art student's creativities. MIT, based on the approach that individuals with different characteristics cannot learn in the same way, each individual is different from each other and all of them can learn, advocates that individual differences between students should be defined and education should be shaped considering these differences (Gardner, 1983).

Gardner, beginning to investigate cognitive capacity of individuals in 70 s and 80 s after studying classical intelligence understanding, stated that each individual has various abilities and mental capacity, after that, introduced MIT in the scope of a cognitive study "Zero Project" at Harvard University and expressed the Theory in the book "Frames of Mind" in 1983.

MIT, developed by Gardner, involves 8 mental dimensions defining individual differences.

Verbal - linguistic intelligence; it can be summarized as the individual ability to use effectively the concepts belonging to 
language. The most apparent characteristics of the individuals having such kind of intelligence are that they can exhibit better speaking, listening, reading and writing skills and effective communication and learning approaches.

Logical - Mathematical intelligence; This mental area can enable individual to use actively the skills such as guessing, thinking imaginary, setting cause - effect relation, comprehending complex relations, analysing, foreseeing and criticising.

Visual - spatial intelligence; it is the ability of individuals to perceive visually the world around them. Individuals with developed visual - spatial intelligence can rapidly recognise and remind the figures, forms, shapes, symbols, visual publications and colours around them.

Bodily - kinaesthetic intelligence; individuals with such intelligence are capable of using their bodies to express their senses and thoughts and they can reveal easily their feelings through movements, gestures and mimics.

Musical - rhythmic intelligence; the most important characteristics of this intelligence type is that individuals can think, comment and communicate musically.

Social Intelligence; Individuals with developed social intelligence have also advanced communicative skills. They can easily understand feelings, thoughts and manners of individuals around them while they are transferring their own feelings and opinions to others.

Intrapersonal Intelligence; It is the most used intelligence area in daily life. It is the ability of individuals to be conscious about their own limits by knowing themselves and direct their movements depending on this knowledge.

Naturalist Intelligence; this type of intelligence is developed among those knowing the characteristics and living conditions of all animals in the nature.

One or more intelligence types can be seen in individuals. Whatever the intelligence types, each individual has absolutely weak or strong aspects. In education and teaching media, only the use of some of such intelligence types may cause unfavourable effects for the students with different intelligence properties. Such students may either achieve learning for longer periods by discovering their own abilities late or not achieve learning activities by not discovering them. In a study (Yavuz 2002), it was stated that when a student with developed visual spatial intelligence is given chance to draw figures and paint pictures of the problem he/she reads or when pictures rather than numbers are placed, the attitude of the same student towards mathematic which he/she finds difficult begins to change and his/her success may increase.

According to MIT, the objective of education is not only to increase academic success of students, but also to discover multi intelligence potentials in students and develop them. MIT attracts attention to individual differences and foresees a change from teacher centred understanding to student centred one (Saban, 2001). According to Armstrong (1994), the best way to use MIT in developing program is to think about the adjustment of the subject to be taught from one intelligence type to another. In other words, the main problem is how to set up the ties between linguistic symbol system and visual, musical, bodily, logical, social and internal intelligences.

MIT is a method advocating bringing different approaches to differences and focusing on what individuals can do rather that what actually they do. In addition, it defends that an education type designed for different thinking patterns of individuals can result in effective outcomes on all individuals. One of the areas this understanding affect the most is visual arts education. One of the most important findings of this theory for visual arts education is that artistic learning is also a cognitive activity. Gardner stated based on his own results that artistic learning is absolutely a cognitive activity (Zessoules et al., 1993) since students acquire several cognitive, emotional and psychomotor skills. According to Eraslan Taspinar and Pazarlioglu Bingol (2014), students use several skills simultaneously like analysing real objects, gaining and advocating opinions, comparison, inferring, regulation, networking, evaluation of claims and problem solving" when they are working on paintings or $3-\mathrm{D}$ images. These skills students acquire may vary depending on their individual differences.

Differences between students can be apparent in visual arts classes. Some students may be more talented and benefit from their visual perceptions more than others. Students with different intelligence types may have different visual perceptions. Students with different intelligence types such as linguistic, mathematical, spatial, kinaesthetic and bodily intelligence are thought to express themselves better when carrying out 3-D works and paintings in educational processes compatible with their intelligence types. It is expected that MIT of Gardner will increase students' success in visual arts class and contribute positively to the permanence of knowledge students learned.

\subsection{Objective of the Study and Research Questions}

Objective of the present study is to determine the effect of MIT based teaching on students' success and permanence of knowledge they learned in visual arts. In convenience with this basic objective, the questions related to sub-objectives 
given below tried to be answered.

In the flow of the subject of miniature in the scope of visual arts at $8^{\text {th }}$ grade,

Research Question 1. Is there any statistically significant difference between the success scores the control and experimental students exposed to MIT based and classical teaching respectively got in success test?

Research Question 2. Is there any statistically significant difference between the permanence scores the control and experimental students exposed to MIT based and classical teaching respectively got in success test?

\section{Method}

\subsection{Research Model}

Experimental design was used in the study to determine the effect of MIT based teaching on students' attitude towards the school subject $8^{\text {th }}$ grade visual art. Control and experimental groups were assigned unbiasedly and measurements were performed before and after the experiment in both groups (Karasar, 2008).

In experimental group, MIT based class activities were performed for three weeks over totally two hours a week (40+40 minutes) while in control group classical teaching method was applied for the same time period. Success test applied at the end of the teaching activities to determine the success of the students was reapplied three weeks later this time to test permanence of the knowledge they learned.

\subsection{Study Group}

Study group is composed of the students at $8^{\text {th }}$ grade at Classroom A and B at Iğdir Ataturk Secondary School in 2012-2013 educational term. Control and experimental students were determined in unbiased assignment and class A was chosen to be control (31 students 49.20\%) and B was experimental group (32 students 50.79\%). The number of female students was $16(50 \%)$ and $15(48.38 \%)$ in experimental and control groups, respectively.

\subsection{Data Collection Tools}

Data were collected using MI Inventory and success test.

MI Inventory: An adjusted MI inventory was used in the study, which was developed by Gardner based on MIT and improved by Harms including nature intelligence. The inventory, translated into Turkish by Oral (2001) was adjusted by Kanat (2008) to secondary school level. The inventory involved totally 10 items for each intelligence field overall 80 items. Each item was scored with points between 1 and 5. Therefore, participants could get maximum 50 points from each intelligence field. Consistency coefficient of the inventory was 0.834 for Cronbach Alpha.

Success test: This test was developed by the researchers to determine the success of students and permanence of their knowledge in visual art class at $8^{\text {th }}$ grade. Totally 20 multiple - choice trial questions were prepared and submitted to expert view. A table of specification was used to provide content validity. A pilot study was conducted in Mehmet Akif Ersoy Secondary School in Iğdır city centre to determine the confidence of the test before the application. Answer sheets obtained from the pilot application were exposed to treatment using test development techniques. According to the technique, each question of the test was given 1 point if answered correctly, 0 if blank, answered wrongly or multi chosen. The test included totally 19 questions in its final version by excluding the distinguishing ones with the score under 0.30 . From the confidence analysis results, KR 20 confidence coefficient was found to be 0.84 . from this point of view, it may be stated that the test including 19 questions is highly confident.

This test was applied to experimental and control groups at the end of the process as success test and reapplied three weeks after the first one to determine the permanence level of the knowledge the students learned.

\subsection{Application and Process}

Introduction and preparatory week: Students in experimental group and researchers were introduced to each other. Students were informed about the subject, objectives and technique of the study to be conducted. By answering students' questions MI inventory and student identification form were used. By giving information about the class activity the next day students were asked to search for miniature as a subject and the lesson finished.

First week: Students were categorised into intelligence groups according to the results obtained from MI inventory. Students were given their works according to their groups and work plans were prepared. According to this plan following items were determined.

Verbal intelligence: students with this type of intelligence field were asked to write story about the event in miniature sample.

Mathematical-logical intelligence: Students were asked whether geometric forms were used in the miniature sample, what the symmetry is, whether the symmetry was used on the sample, if yes how it was used. Technique of the study to 
be conducted was expressed and the students were asked to compare miniature art and today's painting art in a deductive manner.

Visual-spatial intelligence: the subject was expressed on the miniature examples shown to students and following questions were used in class.

- Which art form does the work you are examining belong to? (picture, sculpture, ceramic)

- What can you see in the picture?

- What is happening in it?

- What type of tissue is there on the picture?

- How are the colours designed?

- Are light colours used mostly?

- Which lines do you see?

- Are some of the objects in front or some are back?

- Are there any repetitive figures?

- Are the objects (or people) you see in the picture in their real sizes?

- What attracted your attention the most at your first sight?

- What techniques may the artist have used while painting this picture?

- What does this picture tell in your opinion?

- What do the colours in here make you feel?

- What do you feel when you touch it?

- What kind of voice do you hear?

- Do you think this picture is beautiful? Why?

Bodily - kinaesthetic intelligence: Students with verbal intelligence area were asked to play the story they wrote for the event told in the sample miniature picture and the role plays were video recorded.

Musical and rhythmic intelligence: students were asked to write song words related to sample miniature work.

Social intelligence: in order to set up the communication between students, buzz groups were formed (buzz 66) and 6 students were given opportunities to discuss about the miniature picture for 6 minutes.

Intrapersonal intelligence: students with this intelligence type were asked to write diary about the subject taught in visual arts subject.

Naturalist intelligence: students were asked to write the name of the objects used in the miniature given to them.

Second week: Students divided into groups according to their intelligence fields were shown a presentation prepared by researchers. Students with verbal intelligence presented the story they were asked to write about the event in the sample miniature picture to the classroom and the presentations were video recorded. Students with musical and rhythmic intelligence field read the song words they wrote about the sample miniature work in the classroom and their presentation was recorded.

Third week: Success test prepared by the researchers was applied to measure the students' success.

Permanence test was applied three weeks after the success test in order to determine the permanence of students' knowledge.

\subsection{Data Analysis}

Statistical analysis of data was performed through SPSS 17 software package and $t$ test was used to compare the success and permanence of experimental and control groups.

\section{Results and Discussion}

\subsection{Research Question 1}

Table 1 represents the presence of the difference between experimental and control groups in success scores of students taught miniature pictures using techniques based on MIT and classical methods, respectively. 
Table 1. Success test scores of experiment and control groups

\begin{tabular}{llllll}
\hline Groups & $\mathrm{N}$ & $\bar{X}$ & $\mathrm{~S}$ & $\mathrm{Sd}$ & $\mathrm{t}$ \\
\hline Experiment & 32 & 15,96 & 2,64 &, 46 & 9,12 \\
$\mathrm{p}$ & 31 & 10,09 & 2.45 &, 44 & \\
Control & & & & &
\end{tabular}

It is seen from Table 1 that mean success scores of experimental and control groups are $\bar{X}=15.96$ and $\bar{X}=10.09$, respectively. The difference between two groups is statistically significant $(\mathrm{t}=9,12 ; \mathrm{P}<0.05)$. The difference is on behalf of experimental group and MIT has positive effects on the increase of success scores.

Such findings are in convenience with the results of other studies investigating the positive effects of teaching techniques based on MIT.

In a study (Ayaydin 2005), where MIT based techniques were compared with those classical ones, it was stated that in painting class at primary school, the use of MIT activities increased the success of students and the difference between the success scores of control and experiment groups in which classical and MIT based teaching techniques were applied was found to be statistically significant.

Hanley, et al. (2002) studied the effects of the use of MIT in social works on student interest and success and according to their results the application of MIT in social works increased the success and interest of students.

Vural (2005) stated that each intelligence has its unique education and learning tools and techniques. In the formation and enrichment of education and teaching programs multiple intelligence types may also have unique techniques. With the use of MT in teaching media in classes, right and left lobes of brain may be activated and its use percentage may be increased. When brain works actively, high skills of thinking will develop, dream power will increase and learning activity occurs more frequently. Vural (2005) also stated that when 8 different learning ways are used effectively learning rate increases significantly to reach maximum. Media where different learning methods are offered and pleasant and exciting learning experiences are provided are undoubtedly the most productively and developing environments for students' education and learning.

Bacanlı (2005) reported that performing an education suitable for intelligence types of students can increase their success. In reverse words, some students have difficulties in learning in the absence of the teaching activities liable for their own intelligence types. Therefore, what is expected from teacher to plan and implement educational activities for all students in the classroom.

\subsection{Research Question 2}

Table 2 represents the presence of difference between experimental and control groups in permanence of knowledge among students taught miniature pictures using techniques based on MIT and classical methods, respectively.

Table 2. Results of permanence test in experimental and control groups

\begin{tabular}{llllll}
\hline Groups & $\mathrm{N}$ & $\bar{X}$ & $\mathrm{~S}$. & $\mathrm{Sd}$ & $\mathrm{t}$ \\
\hline Experiment & 32 & 15,87 & 2,19 &, 38 & 12,79 \\
$\mathrm{p}>0.05$ & 31 & 8.54 & 2,35 &, 42 & \\
Control & & & & &
\end{tabular}

It can be seen when the table is considered that mean permanence score of the students in experimental and control groups is $X=15.87$ and $X=8.54$, respectively. It was determined according to the results obtained that the difference between experimental and control group is statistically significant $(\mathrm{t}=12.79 ; \mathrm{P}<0.05)$.

It can be stated that knowledge students learned is more permanent among those in experimental group than the control.

It was reported in a study (Kilic Demirkaya 2006) that MIT based teaching affected positively the success and permanence of $6^{\text {th }}$ grade students in music classes compared to control group applied a teaching method based on a conventional method. Results of the present study are in convenience with the mentioned study.

It was also found in another study (Guler Karadeniz 2006) that in English class MIT based teaching affected positively the success and permanence among $9^{\text {th }}$ grade students at Anatolian High school.

According to findings, teaching based on MIT was found to affect positively the permanence of knowledge the students.

\section{Conclusion and Suggestions}

\subsection{Conclusion}

In the present study, effects of MIT on S and P scores of students at $8^{\text {th }}$ Grade for miniature picture subject in visual arts 
classes are investigated using MIT in experimental and a classical method in control group. Conclusions are given as follows.

1. Teaching based on MIT affected the success of students significantly and favourably among the student group and class mentioned above. Such a result may show that success of students may be increased through the activities designed for the intelligent types they have stronger.

2. Teaching based on MIT affected the permanence of knowledge students mentioned above learned significantly and positively.

\subsection{Suggestions}

It should be targeted that in the planning and application of classes, instead of the use of only one teaching method and technique, all students should be reached by using different teaching methods and techniques. Teachers should bear in their mind that in planning their classes, interest, learning style and ability of each student are different from others. Researches in longer time periods and on larger groups based on MIT can help educationists. New teaching methods based on MIT should be developed to turn the differences between students into advantages and used in visual arts education.

\section{References}

Armstrong, T. (1994). Multiple Intelligences In The Classroom. Alexandria: ASCD Virginia.

Ayaydın, A. (2005). İlköğretim Resim-Is Dersinde Çoklu Zeka Kuramına Dayali Oğretim Yonteminin Ogrenci Başarisina Etkisi. Yayımlanmamıs Doktora Tezi. Gazi Üniversitesi Eğitim Bilimler Enstitusu, Ankara.

Bacanli, H. (2005). Gelisim ve Ogrenme. (10. Bask1). Ankara: Nobel Yayınlari.

Eraslan, T. S., \& Pazarlioğlu, B. M. (2014). Sanat Egitimi ve Elestirel Dusunme, Managing The Art, An International Conference on Art, 4-7 November, Yıldız Technical University, Faculty of Art and Design, İstanbul / Turkey.

Erden, M., \& Akman, Y. (2009). Egitim Psikolojisi, “Gelisim-Ogrenme-Ogretme. (18. Baski). Ankara: Arkadas Yayinevi.

Gardner, H. (1983). Frames of Mind, The Theory of Multiple Intelligences (Second Edition). London: Harper Collins Publishers.

Guler, K. N. (2006). Coklu Zeka Kurami Tabanli Ogretimin Anadolu Lisesi 9. Sinif Ogrencilerinin Ingilizce Dersindeki Basarılarina ve Ogrenilen Bilgilerin Kaliciligina Etkisi. Yayimlanmamis Yuksek Lisans Tezi. Suleyman Demirel Universitesi Sosyal Bilimler Enstitusu, Isparta.

Hanley, C., Hemiz, C., Lagioia-Peddy, J., \& Levine-Albuck, V. (2002). Improving Student Interest And Achievement Is Social Studies Using A Multiple Intelligence Approach, Yüksek Lisans Tezi. Saint Xavier University. United State.

Kanat, S. (2008). Gorsel Sanatlar Dersinde Coklu Zeka Kuramina Dayali Ogretim Yonteminin 7. Sinif Ogrencilerinin Erisine ve Öğrendikleri Bilgilerin Kaliciligina Etkisi (Malatya Ili Fatih Ilköğretim Okulu). Yayımlanmamis Yuksek Lisans Tezi. İnonu Universitesi Sosyal Bilimler Enstitusu, Malatya.

Karasar, N. (2008). Bilimsel arastirma yontemi. (18. Basim). Ankara: Nobel Yayin Dagitim.

Kilic, D. E. (2006). Ilkogretim Okulu Muzik Derslerinde Coklu Zeka Kurami'na Dayali Ogretimin 6. Sinif Ogrencilerinin Basarisina ve Ogrendikleri Bilgilerin Kaliciligina Etkisi. Yayimlanmamis Yuksek Lisans Tezi. Abant Izzet Baysal Universitesi Sosyal Bilgiler Enstitusu, Bolu

Oral, B. (2001). Branslarina Gore Universite Ogrencilerinin Zeka Alanlarinin Incelenmesi. Egitim ve Bilim, 26 (122), 19-31.

Parasiz, G. (2009). Keman egitiminde kullanilmakta olan cagdas Turk muzigi eserlerinin seslendirilmesine yonelik olarak olusturulan hazirlayici alistirmalarin isgorusellik ve etkililik yonunden incelenmesi. Yayımlanmamıs Doktora Tezi. Gazi Üniversitesi Eğitim Bilimler Enstitusu, Ankara.

Vural, B. (2005). Ogrenci Merkezli Egitim ve Coklu Zeka. (3. Baski). Istanbul: Hayat Yayıncilik.

Yavuz, K. E. (2002). Coklu Zeka Teorisi, Yeni Egitim Dergisi, 1, 40-42.

Zessoules, R., Wolf, D. P., \& Gardner, H. (1993). A Better Blance: Arts Propel as an Alternative to Discipline-Based Art Education, Discipline-Based Art Education and Culturel Diversity, Printed in United States of America.

This work is licensed under a Creative Commons Attribution 3.0 License. 